\title{
AUNC
}

Zabytkoznawstwo i Konserwatorstwo XLIX

Toruń 2018

DOI: http://dx.doi.org/10.12775/AUNC_ZiK.2018.003

\section{Historia przekształceń siedemnastowiecznego kościoła w zespole klasztornym Karczówka (Kielce) w świetle analizy więźb nawy i prezbiterium}

\author{
MACIEJ PRARAT \\ Zakład Konserwatorstwa \\ Wydział Sztuk Pięknych, UMK w Toruniu \\ e-mail:mprarat@umk.pl \\ ORCID: 0000-0001-7076-2009
}

Key words: architectural research, timber roof truss, religious architecture, świętokrzyska Land, historical building technologies

Słowa klucze: badania architektoniczne, więźba dachowa, architektura sakralna, ziemia świętokrzyska, historyczne techniki budowlane

\section{Abstract \\ History of the $17^{\text {th }}$ century Karczówka monastery church (Kielce) in the light of changes of the roof constructions above the nave and the chancel.}

A 17th-century church in a monastery complex on the Karczówka Hill in its current borders has been an object of interest of numerous researchers. However, due to insufficient written sources, its building history has not been fully recognized. The aim of this paper is to present the results of architectural research of the roof constructions above the nave and the chancel in connection with the walls and the gables of the church. They have been significantly changed; yet, originally, they constituted three types of trusses: single collar beam truss and king post truss above the chancel, triple collar beam roof and king post truss with a double standing truss above the west arch of the nave, double collar beam roof and king post truss with a double standing truss above the east arch of the nave. Selected elements of the three constructions have been also studied in terms of dendrochronology. The original church (built after 
1622) was half as wide as today's nave. It was not possible to identify whether the chancel was built at the same time. In the second stage (1628) the nave was extended with the east arch. The following changes of wooden constructions and the church walls themselves took place in the 1640 s and 1650s in relation to the extension of the monastery wings.

\section{Abstrakt}

XVII-wieczny kościół w zespole klasztornym na wzgórzu Karczówka w obecnych granicach Kielc był już przedmiotem zainteresowania wielu badaczy. Wobec skromnych źródeł pisanych jego historia budowy nie była jednak w pełni rozpoznana. Celem niniejszego tekstu jest prezentacja wyników badań architektonicznych konstrukcji dachowych nad nawą i prezbiterium w powiązaniu ze ścianami i szczytami świątyni. Dziś znaczenie przekształcone, pierwotnie tworzyły trzy typy więźb: jednojętkową, storczykową nad prezbiterium; trójjętkową, storczykową z ramą stolcową nad przęsłem zachodnim nawy; dwujętkową, storczykową z ramą stolcową nad przęsłem wschodnim nawy. Wytypowane elementy z trzech konstrukcji przebadane zostały również dendrochronologicznie. Pierwotny kościół (powstały po 1622 r.) miał szerokość połowy dzisiejszej nawy. Nie udało się jedynie określić, czy wraz z nim powstało również prezbiterium. W drugim etapie (1628 r.) rozbudowano nawę o przęsło wschodnie. Kolejne przekształcenia konstrukcji drewnianych jak i samych murów kościoła miały miejsce na przełomie lat 40. i 50. XVII w. w związku z dobudową skrzydeł klasztornych.

\section{Wstęp}

Jednym z cenniejszych zabytków nowożytnej architektury sakralnej na ziemi świętokrzyskiej jest pobernardyński zespół klasztorny Karczówka, położony na wzgórzu w zachodniej części dzisiejszych Kielc. Cały zespół, otoczony kamiennym murem, tworzą trzy jego integralne części: kościół usytuowany skrajnie po stronie zachodniej, czworoboczny klasztor z wewnętrznym wirydarzem oraz zabudowania gospodarcze $\mathrm{z}$ drugim dziedzińcem od strony wschodniej. Na obecną rozczłonkowaną bryłę kościoła składa się dwuprzęsłowy korpus nawowy na rzucie prostokąta oraz niższe i węższe jednoprzęsłowe prezbiterium od strony zachodniej, z małą zakrystią od północy; dostawiony od wschodu wąski przedsionek łączy świątynię z wieżą (il. 1). Wszystkie części kościoła kryją dwuspadowe dachy o zróżnicowanej wysokości kalenicy. Do przedsionka i południowego skrzydła klasztornego przylega wyższa i nieco szersza kruchta, nakryta wysokim dachem namiotowym, do której prowadzą trójbiegowe schody rozbieżno-zbieżne z podestem. Od strony południo- 
wej do korpusu nawowego dochodzi prostokątna kaplica. Od północy na całej długości korpusu biegnie wąski, niski korytarz nakryty dachem pulpitowym. W dotychczasowych badaniach podejmowano szereg zagadnień dotyczących historii klasztoru, jego architektury i wyposażenia ${ }^{1}$, lecz były one oparte głównie na analizie styloznawczej oraz dość skromnej bazie materiałów źródłowych. Do dziś nie rozpoznano struktury materialnej całego zespołu ani nie przeprowadzono rzetelnej kwerendy źródłowej²

Zob. pierwszą monografię zespołu: Józef Zdanowski, Karczówka pod Kielcami (Kielce: 1928), dostęp 25.06.2017, http://www.galeriaswietokrzyska.wici.info/archiwum/karczowka-zdanowski.pdf. Z nowszych opracowań zob. Katalog zabytków sztuki w Polsce, t. 3 Województwo kieleckie, red. Jerzy Łoziński, Barbara Wolff, z. 4 Powiat kielecki, oprac. Tadeusz Przypkowski (Warszawa: Państwowy Instytut Sztuki 1957), 42-43; Jerzy Łoziński i Adam Miłobędzki, Atlas zabytków architektury w Polsce (Warszawa: Wydawnictwo „Polonia”, 1967), 91; Zofia Stobiecka, „Pobernardyński zespół kościelno-klasztorny na Karczówce”, Rocznik Muzeum Świętokrzyskiego 8 (1973): 275-304; Anna Adamczyk, „Architektura zespołu klasztornego na Karczówce”, w Karczówka. Historia, literatura, architektura, przyroda, red. Jerzy Leszek Olszewski (Kielce: Kieleckie Towarzystwo Naukowe 1995), 51-72; Anna Piasecka, „Kronika prac remontowo-konserwatorskich zrealizowanych w zespole kościoła i klasztoru bernardynów na Karczówce w latach 1945-1993”, w Karczówka. Historia, 73-77; Jakub Lewicki, „Kilka uwag na marginesie monografii bernardyńskiego zespołu klasztornego na Karczówce pod Kielcami”, Kwartalnik Architektury i Urbanistyki 43, z. 3 (1998): 273-280; Jakub Lewicki, recenzja z Karczówka. Historia, literatura, architektura, przyroda, red. Jerzy Leszek Olszewski, Ochrona Zabytków 51, nr 2 (1998): 181-187; Marta Pieniążek-Samek, Tributum Gratitudinis Reddo. Fundacje artystyczne na terenie Kielc w XVII i XVIII wieku. Studium z historii kultury (Kielce: Kieleckie Towarzystwo Naukowe, Wydawnictwo Jedność, 2005); Kinga Blaschke, „Kościół na Karczówce. Zapomniane sanktuarium św. Karola Boromeusza”, w Święty Karol Boromeusz a sztuka w Kościele powszechnym, w Polsce, w Niepołomicach, red. Piotr Krasny, Michał Kurzeja (Kraków: DodoEditor; Niepołomice: Muzeum Niepołomickie w Zamku Królewskim, 2013), 77-99; Dzieje Karczówki w Kielcach w latach 1624-2024, t. 1 Początki fundacji, insygnia, fundator, red. Jerzy Michta (Kielce: Muzeum Historii Kielc, 2016), tu podsumowanie starszej literatury przedmiotu. O wyposażeniu świątyni zob. Mieczysław Morka, „Figura św. Barbary w klasztorze na Karczówce w Kielcach”, Biuletyn Historii Sztuki 40, nr 4 (1978): 377-399; Marta Michałowska, Zabytkowe tekstylia kieleckie (Warszawa: Ośrodek Dokumentacji Zabytków, 1989); Cyprian Moryc, „Galeria portretowa wybitnych bernardynów jako wyraz plastyczny ideału doskonałości zakonnej promowanego w środowisku bernardyńskim w XVII i XVIII w.”, w Studia nad sztukq renesansu i baroku, t. 10 Programy ideowe w przedsięwzięciach artystycznych w XVI-XVIII wieku, red. Irena Rolska-Boruch (Lublin: Towarzystwo Naukowe KUL, 2010), 265-293. Zob. też Dawid Kukła i Michał Pawlicki, Karczówka. Bibliografia w wyborze, (Kielce: [wyd.], 2012), dostęp: 20.06.2017, http://sbc.wbp.kielce.pl/ Content/16075/KARCZ\%C3\%93WKA_bibliografia\%20w\%20wyborze.pdf.

2 Klasztor i kościół zostały osobno wpisane do rejestru zabytków już w 1932 r., natomiast zespół klasztorny jako całość w 1967 r. (pod nr. 257). Zob. Rejestr zabytków nieruchomych woj. świętokrzyskiego (stan z dnia 30.10.2016 r.), dostęp 18.08.2017, http://wuoz.kielce.pl/p,98,rejestr-zabytkow-nieruchomych. W archiwum Wojewódzkiego Urzędu Ochrony Zabytków (dalej: WUOZ) w Kielcach znajduje się podstawowa dokumentacja zespołu, zob. Janusz Wic, „Klasztor bernardynów, Kielce-Karczówka. Karta Ewidencji Zabytków Architektury i Budow- 
Celem niniejszego tekstu jest prezentacja wyników badań drewnianych konstrukcji dachowych, w połączeniu z murowaną strukturą poddasza kościoła ${ }^{3}$ Poza opisem analitycznym więźb, przedstawione zostanie ich rozwarstwienie chronologiczne oraz próba hipotetycznej rekonstrukcji stanu pierwotnego ${ }^{4}$. Uzyskane ustalenia zostaną odniesione do dotychczasowego stanu badań dotyczących przekształceń budowlanych najstarszego budynku na wzgórzu klasztornym.

Prezentowane szczegółowe wyniki analizy dotyczą jedynie zadaszenia nad nawą i prezbiterium, bez uwzględnienia struktury wieży i sygnaturki. Z powodu otynkowania całego budynku, jedynie ten fragment mógł być poddany nieinwazyjnemu rozpoznaniu. W ramach badań sporządzono ogólną charakterystykę konstrukcji, przeanalizowano wielkość budulca oraz jego obróbkę, system ciesielskich znaków montażowych, a także wszystkie złącza i ślady po nich ${ }^{5}$. Na podstawie rozwarstwienia względnego, wytypowano grupy elementów więźb do badań dendrochronologicznych.

nictwa”, Kielce 1996, WUOZ w Kielcach); Janusz Wic, „Kościół parafialny pw. św. Karola Boromeusza w zespole klasztornym Kielce-Karczówka. Karta Ewidencji Zabytków Architektury i Budownictwa”, Kielce 1996, WUOZ w Kielcach); Janusz Wic, „Zabudowania gospodarcze w zespole klasztornym Kielce-Karczówka. Karta Ewidencji Zabytków Architektury i Budownictwa”, Kielce 1996, WUOZ w Kielcach); Janusz Wic, „Zespół klasztorny bernardynów, Kielce-Karczówka. Karta Ewidencji Zabytków Architektury i Budownictwa”, Kielce 1996, WUOZ w Kielcach).

3 Analizy zostały wykonane w ramach badań architektonicznych części wschodniej świątyni na styku z założeniem klasztornym. Zob. Beata Piaskowska, „Inwentaryzacja pomiarowo-rysunkowa części wschodniej kościoła pw. św. Karola Boromeusza w zespole klasztornym Karczówka”, Toruń-Karczówka 2017, WUOZ w Kielcach); Maciej Prarat, „Badania architektoniczne części wschodniej kościoła pw. św. Karola Boromeusza w zespole klasztornym Karczówka”, Toruń-Karczówka 2017, WUOZ w Kielcach); Tomasz Ważny, „Badania dendrochronologiczne wieży, nawy i prezbiterium kościoła pw. św. Karola Boromeusza w zespole klasztornym Karczówka”, Toruń-Karczówka 2017, WUOZ w Kielcach).

4 Na temat podstawowej terminologii i typologii więźb dachowych w Polsce zob. Jan Tajchman, „Propozycja systematyki i uporządkowania terminologii ciesielskich konstrukcji dachowych występujących na terenie Polski od XIV do XX w.", Monument. Studia i Materiały Krajowego Ośrodka Badań i Dokumentacji Zabytków 2 (2005): 7-35, tam też starsza literatura przedmiotu. Zob. również Dominik Mączyński, Jan Tajchman, Maciej Warchoł, „Materiały do terminologii więźb dachowych - podstawowe pojęcia”, Monument. Studia i Materiały Krajowego Ośrodka Badań i Dokumentacji Zabytków 2 (2005): 37-43.

5 Więcej na temat metody badań zob. Ulrich Schaaf, „Metody i formy dokumentacji badań architektonicznych konstrukcji szkieletowych na wybranych przykładach śląskich Kościołów Pokoju”, w Badania architektoniczne. Historia i perspektywy rozwoju, red. Marian Arszyński et al. (Toruń: Wydawnictwo Bernardinum, 2015), 155-183. 


\section{Historia kościoła}

Świątynia została ufundowana przez biskupa krakowskiego Marcina Szyszkowskiego, jako wotum złożone przez niego w 1622 r., podczas zarazy. Akt erekcyjny wystawiono 2 maja $1624 \mathrm{r}^{7}$ - w tym czasie mury kościoła były już ukończone ${ }^{8}$; w następnym roku biskup uposażył parafię. Prace budowlane ostatecznie ukończono w roku 1628, informuje o tym tablica umieszczona w murze obecnego zachodniego skrzydła klasztoru. W tym samym roku, 4 października do świątyni - wtedy parafialnej w osadzie górniczej - przeniesiono relikwie św. Karola Boromeusza z kolegiaty kieleckiej, której wikariusze zarządzali parafią.

Forma kościoła była przez dotychczasowych badaczy różnie interpretowana. Józef Zdanowski uważał, że zbudowano go w kilku fazach, poczynając od zachodniej części nawy, a następnie wznosząc część wschodnią i prezbiterium, przy czym ostatecznie miał stanąć w 1628 roku$^{9}$. Zofia Stobiecka prostą formę świątyni budowanej w latach 1622-1628 łączyła z lokalnym warsztatem kieleckim, tkwiącym jeszcze w tradycji gotyckiej ${ }^{10}$. Odmiennego zdania była Marta Pieniążek-Samek, dopatrująca się tu wzorców krakowskich ${ }^{11}$. Polemizowała z nią Kinga Blaschke, która tę formę utożsamiała z „nurtem oszczędnej, programowo skromnej architektury bernardyńskiej pierwszej połowy XVII w.”, analogicznie do kształtu kościołów w Świętej Katarzynie i Kalwarii Zebrzydowskiej (przed osiemnastowieczną rozbudową) oraz kościoła Reformatów w Solcu ${ }^{12}$. Z najstarszego okresu funkcjonowania świątyni zachował się ołtarz główny ${ }^{13}$ i pierwotnie zewnętrzny portal (obecnie umieszczony między przedsionkiem a nawą) z datą $1628^{14}$. Kolejne przekształcenia

6 Z racji zawężonych ram, w tekście tym zawarto jedynie podstawowe informacje, mogące być punktem odniesienia do przekształceń samego kościoła, bez szczegółowej charakterystyki zmian w zespole klasztornym.

7 Stobiecka, „Pobernardyński zespół”, 280; Adamczyk, „Architektura”, 53.

8 Cytat z 5 IV 1624 r.: „uczyniłem votum in honorem B. Boromei capellę zmurować na górze przy Białogonie, którą jużem murami wywiódł i prędko się zasklepi” - cytat za: Pieniążek-Samek, Tributum, 354.

9 Zdanowski, Karczówka, 17.

10 Stobiecka, „Pobernardyński zespół”, 286.

11 Pieniążek-Samek, Tributum, 160.

12 Blaschke, „Kościół”, 83, 84.

13 Podsumowanie badań ołtarzy zob. Blaschke, „Kościół”, 86-88.

14 Odnośnie proweniencji, Z. Stobiecka sugeruje krakowskich kamieniarzy w warsztatach pińczowskich, co zostało zakwestionowane przez K. Blaschke. Zob. Blaschke, Kościót, 84, przyp. 42. 
wprowadzono w trakcie rozbudowy w latach trzydziestych i czterdziestych XVII wieku, po przejęciu świątyni przez bernardynów - ich klasztor erygowano 2 sierpnia $1631 \mathrm{r}$. Między innymi od wschodu dostawiono do kościoła przedsionek wraz z wieżą, skomunikowaną z zachodnim skrzydłem klasztornym. Z kolei w kościelnym wnętrzu między dwa przęsła nawy wstawiono dwa wydatne filary przyścienne i połączono je arkadą. Zdaniem Anny Adamczyk przyczyną tej zmiany była potrzeba przedłużenia chóru konwentualnego, według innej hipotezy chodziło o pozyskanie przestrzeni na zainstalowanie ołtarzy niezbędnych w konwencie bernardyńskim ${ }^{15}$. W XVIII wieku przebudowano sygnaturkę i hełm wieży, dostawiono również od południa kruchtę ze schodami ${ }^{16}$.

W roku 1864 klasztor został skasowany przez władze carskie. Od tego czasu stan zespołu klasztornego stale się pogarszał. Dopiero na przełomie XIX i XX wieku przeprowadzono większy remont obiektów, m.in. dach kościoła pokryto dachówką, a sygnaturkę blachą. W dolnej kondygnacji wieży urządzono kaplicę św. Barbary. Obniżono poziom posadzki w nawie kościoła i rozebrano dwa filary wraz z arkadą między przęsłami sklepień, wykonując $\mathrm{w}$ ich miejsce pilastry ${ }^{17}$. Przemurowano również częściowo sklepienie od strony chóru ${ }^{18}$. Po drugiej wojnie światowej zespół klasztorny wszedł we władanie księży pallotynów, którzy użytkują go do dziś.

\section{Więźba nad prezbiterium \\ (opis analityczny, rozwarstwienie, rekonstrukcja) (il. 2, 3)}

Drewniana konstrukcja nad prezbiterium składa się z pięciu wiązarów ${ }^{19}$. Obecnie jest to więźba jednojętkowa, z ramą stolcową. Stolce znajdują się na osi trzech wiązarów dachowych: $\mathrm{nr}$ 1, 3 i 5. Wiązary nr 2, 3, 4 odwiązane są w kierunku zachodnim, nr 5 zaś we wschodnim ${ }^{20}$.

\footnotetext{
Adamczyk, „Architektura”, 62.

16 Więcej na temat przekształceń tej części zob. Zdanowski, Karczówka, 22; Łoziński i Miłobędzki, Atlas, 91; Katalog, 44; Stobiecka, „Pobernardyński zespół”, 294; Adamczyk, „Architektura”, 67; Karol Guttmejer, Guido Antonio Longhi. Działalność architektoniczna w Polsce (Warszawa: Wydawnictwo Neriton, 2006), 55-57; Blaschke, „Kościół”, 86.

17 Adamczyk, „Architektura”, 56.

Zdanowski, Karczówka, 17, przyp. 44.

W il. 3 szczegółowo rozrysowane zostały wiązary nr 2, 3, 4, 5.

Wiązar nr 1 pozostaje nieokreślony.
} 
Belki wiązarowe osadzone są w murłatach na wrąb. Nie są one połączone z murłatami końcowymi, w które wpuszczone są długie przypustnice, sięgające prawie kalenicy ${ }^{21}$. Jętki łączą się z krokwiami na nakładkę o formie połowy jaskółczego ogona, krokwie zaś w kalenicy na styk. Elementy ramy - tj. płatew ze słupem oraz miecze ze słupem i płatwią - łączą się na czop.

Na większości krokwi i jętek znajduje się szereg pustych gniazd, wcześniej wykorzystanych, o czym świadczą dziury po kołkach. Elementy te zostały opracowane ręcznie za pomocą siekiery i topora z całego drzewa ${ }^{22}$ bez oflisów ${ }^{23}$. Mniej dokładnie obrobiono z całego drzewa ramę stolcową z dużymi oflisami. Murłaty i przypustnice wykonano używając piły mechanicznej. Na poszczególnych elementach odnaleziono również system znaków montażowych zrobionych siekierą ${ }^{24}$.

Opierając się na przeprowadzonej analizie określono elementy oryginalne i wtórne. Do pierwotnej konstrukcji należą: w wiązarze nr 2 - obie krokwie; w wiązarze nr 3 - obie krokwie, jętka, belka wiązarowa; w wiązarze nr 4 - obie krokwie, belka wiązarowa; w wiązarze nr 5 - obie krokwie, belka wiązarowa. Na tej podstawie wytypowano elementy do badań dendrochronologicznych. Wynik uzyskano jedynie z dwóch prób, w dodatku z powodu braku słojów podkorowych nie jest on dokładny: elementy sosnowe i jodłowe pochodzą z drzew ściętych po 1589/1594 roku, jednak nie da się ustalić dokładnej daty końcowej ${ }^{25}$.

Do elementów związanych z kolejnymi przekształceniami należą: płatwie, stolce i miecze ram stolcowych; cały wiązar nr 1; w wiązarze nr 2 - belka wiązarowa i jętka; w wiązarze nr 4 - jętka; w wiązarze nr 5 - jętka. Najprawdopodobniej należy je łączyć z pracami remontowymi prowadzonymi w XIX wieku. Wszystkie murłaty, podwaliny i przypustnice wymieniono podczas ostatnich prac remontowych.

21 Być może pierwotnie murłaty pełniły funkcję drewnianych gzymsów.

22 Wymiary wiązarów: nr 5 - krokwie $21 / 13 \mathrm{~cm}, 19 / 13 \mathrm{~cm}$, belka 22/25 cm; nr 4 - krokwie 13/13 cm, 15/13 cm, belka 25/25 cm; nr 3 - krokwie 19/16 cm, 22/13 cm, belka 25/25 cm; nr 2 krokwie $15 / 15 \mathrm{~cm}, 17 / 16 \mathrm{~cm}$, belka $20 / 20 \mathrm{~cm}$.

${ }^{23}$ Mniej dokładnie obrobiono jedynie krokwie wiązara nr 2. W odróżnieniu od reszty w kalenicy łączy się on na nakładkę.

24 Są to: cztery pionowe nacięcia na obu krokwiach wiązara $\mathrm{nr} 2$, trzy nacięcia na obu krokwiach wiązara $\mathrm{nr} 3$, dwa pionowe nacięcia na obu krokwiach wiązara $\mathrm{nr} 4$ oraz jedno pionowe nacięcie na belce wiązara nr 5 .

25 Próby udało się zebrać z 2., 3. i 5. belki wiązarowej, krokwi południowej z wiązara $\mathrm{nr} 2 \mathrm{oraz}$ jętki z wiązara nr 3. Zob. Ważny, „Badania”, nr 19-23. 
Zachowane gniazda po złączach umożliwiają rekonstrukcję pierwotnego układu konstrukcyjnego. Najprawdopodobniej była to więźba storczykowa ${ }^{26}$ o redukcji poprzecznej i podłużnej. Pełny układ miał szczytowy wiązar nr 5 i być może nr 1. Pomiędzy jętką a belką ustawiona była rama storczykowa z podwaliną i górnym ryglem ${ }^{27}$. Sam storczyk zawieszony był prawdopodobnie na zastrzałach wychodzących z krokwi i przechodzących przez jętkę ${ }^{28}$. Krokwie były dodatkowo usztywnione poprzecznie $\mathrm{z}$ belkami wiązarowymi oraz przypustnicami za pomocą mieczy ${ }^{29}$. Podobny do nr. 5., lecz nieco odmienny układ miał wiązar środkowy nr 3 . Długie zastrzały podwieszające storczyk krzyżowały się z kolejną dodatkową parą, łączącą się z krokwiami blisko kalenicy oraz jętką (il. 4). Wiązary nr 2 i 4 były zredukowane poprzecznie i podłużnie.

Wszystkie złącza miały układ nakładkowy o formie połowy jaskółczego ogona lub zaczepowy. Belka wiązarowa łączyła się z murłatami zapewne na wrąb. Odwiązanie wiązara nr 5 od wschodu świadczy, że postawiono go po wymurowaniu szczytu pomiędzy prezbiterium a nawą ${ }^{30}$. Sam szczyt od tej strony jest otynkowany, z dwoma symetrycznymi otworami komunikacyjnymi, zamkniętymi łukiem odcinkowym.

\section{Więźba nawy \\ (opis analityczny, rozwarstwienie, rekonstrukcja) (il. 2, 5, 6)}

Więźba nad nawą składa się z osiemnastu wiązarów ${ }^{31}$; obecnie jest to więźba jętkowa z ramami stolcowymi. Pierwszych jedenaście wiązarów to wiązary trójjętkowe, kolejne siedem - dwujętkowe. Pomiędzy dolnymi jętkami a belkami wiązarowymi znajdują się trzy ramy wzdłużne, składające się z płatwi oraz stolców, wzmocnionych podłużnie mieczami. Dodatkowo w wiązarach $\mathrm{nr}$ 11, 13 i 15 zachowane są storczyki, tworzące środkową ramę usztywniającą.

Wiązary nr 3-11 oraz nr 17 odwiązane są od wschodu, natomiast wiązary $\mathrm{nr}$ 2, 11a-16 - od zachodu. Belki wiązarowe połączone są z murłata-

${ }^{26}$ Jedynie ślady w jętce wiązara nr 3 mogą świadczyć o funkcji słupa środkowego. Zastrzały od krokwi przechodzą bowiem poniżej, przez jętkę, zapewne podwieszając storczyk.

27 Brak elementów ramy nie pozwala na pełną rekonstrukcję układu wzdłużnego.

28 W wiązarze $\mathrm{nr} 5$ nie zachowała się oryginalna jętka. Mieczowanie górne może być zatem tylko hipotezą - na il. 3 przedstawione zostało czerwoną linią.

29 Przypustnice prawdopodobnie od początku znajdowały się w więźbie prezbiterium.

30 Zakładając oczywiście, że podczas późniejszych przekształceń wiązar nie został odwrócony.

31 Analizą objęto tylko więźbę nawy, bez konstrukcji sygnaturki oraz jej wtórnych usztywnień. 
mi (zachowanymi fragmentarycznie) na wrąb. Długie przypustnice wchodzą bezpośrednio $\mathrm{w}$ mur lub częściowo osadzone są w murłatach niepołączonych z belką. Krokwie łączą się z belkami na czop, z tym że wiele gniazd jest zdecydowanie przewymiarowanych. Jętki łączą się z krokwiami na nakładkę zaczepową, o formie połowy jaskółczego ogona lub na czop. Tam, gdzie znajdują się storczyki, jętki jedynie do nich dochodzą ${ }^{32}$. Storczyki są zatem zawieszone tylko na zastrzałach. Miecze stopowe usztywniają belki i krokwie, łącząc się na nakładki o formie połowy jaskółczego ogona lub na styk. Takie same złącza zastosowano w mieczach łączących krokwie z przypustnicami. Ich strona odwiązania nie pokrywa się w wielu przypadkach z odwiązaniem wiązaró $w^{33}$. Występujące $w$ wiązarach ze storczykami dodatkowe usztywnienie mieczami i zastrzałami łączy się na nakładki o formie połowy jaskółczego ogona lub przekładkę skośną z zaciosem. Stolce z płatwiami oraz mieczami łączą się na czopy.

Na krokwiach i jętkach więźby nawy (poza nr. 1.) - podobnie jak na więźbie prezbiterium - znajduje się szereg pustych gniazd. Większość elementów opracowana została ręcznie za pomocą siekiery i topora z całego drzewa (belki wiązarowe, krokwie, podwaliny, storczyki) lub półdrzewa (zastrzały, część jętek) ${ }^{34}$. Obróbka była tak precyzyjna, że nie zachował się tam oflis. Tymi samymi narzędziami, ale zdecydowanie mniej dokładnie wykonano ramę stolcową. Na poszczególnych elementach odnaleziono również system ciesielskich znaków montażowych zrobionych siekierą lub sangwiną ${ }^{35}$.

32 Jętki są dwuczęściowe, łączą się ze storczykiem na czop.

33 W wiązarach nr 1-11 po stronie północnej miecze te znajdują się po drugiej stronie odwiązania wiązarów.

34 Wymiary rozrysowanych wiązarów: $\mathrm{nr} 6$ - krokwie $15 / 20 \mathrm{~cm}$, belka $19 / 25 \mathrm{~cm}$, podwaliny ram stolcowych $21 / 21 \mathrm{~cm}$, przypustnice $13 / 15 \mathrm{~cm}$, miecze $10 / 13 \mathrm{~cm}$; $\mathrm{nr} 8$ - krokwie $22 / 18 \mathrm{~cm}$, belka wiązarowa $23 / 22 \mathrm{~cm}$, przypustnice $16 / 16 \mathrm{~cm}$; nr 11 - krokwie $22 / 15 \mathrm{~cm}$, jętki $16 / 13 \mathrm{~cm}$, storczyk $20 / 25 \mathrm{~cm}$, zastrzały $14 / 13 \mathrm{~cm}, 15 / 10 \mathrm{~cm}$, belka wiązarowa $23 / 22 \mathrm{~cm}$; $\mathrm{nr} 13$ - krokwie $23 / 25 \mathrm{~cm}$, storczyk $18 / 20 \mathrm{~cm}$, jętka $20 / 12 \mathrm{~cm}$, miecze $13 / 13 \mathrm{~cm}$; nr 14 - krokwie 20/14 cm, belka wiązarowa $23 / 20 \mathrm{~cm}$; nr 17 - krokwie $20 / 16 \mathrm{~cm}$, belka wiązarowa $23 / 20 \mathrm{~cm}$, jętka $16 / 18 \mathrm{~cm}$.

35 Na wiązarach: nr 1 - brak znaków; nr 2 - dziesięć kresek siekierą na krokwi północnej, trzy kreski na południowej (z tym, że reszta znaków znalazła się w gnieździe pod miecz); nr 3 dziewięć kresek siekierą na obu krokwiach; nr 4 - osiem kresek siekierą na krokwi północnej, cztery na południowej (z tym, że reszta znaków znalazła się w gnieździe pod miecz); nr 5 siedem kresek siekierą na obu krokwiach; nr 6 - sześć kresek siekierą na obu krokwiach; nr 7 - pięć kresek na obu krokwiach; nr 8 - cztery kreski na obu krokwiach i górnej jętce; nr 9 - trzy kreski na krokwi północnej; nr 10 - dwie kreski na krokwi północnej; nr 11 - brak znaków; nr 12 - brak znaków; nr 13 - znak XX sangwiną dla krokwi, jętki i miecza po stronie południowej, znak $X$ sangwiną dla storczyka, jętki i zastrzałów po stronie północnej; nr 14 - 
Na szczycie zachodnim widoczny jest odcisk pierwotnej konstrukcji pełnego wiązara. Świadczy to o odwiązaniu więźby i dopiero późniejszym wymurowaniu szczytu (il. 7$)^{36}$. Na szczycie wschodnim również jest zachowany odcisk po konstrukcji, jednak innej niż obecny wiązar nr 17 (il. 8). Był to również storczyk. Dowodem na to, że wiązar szczytowy łączył się z układem konstrukcyjnym nr 12-16, jest ślad po górnym ryglu w storczyku nr 15. Przechodził on przez niego, wchodząc w ostatni storczyk [nr 17] - analogiczny zatem do nr. 13. i 15.

Ponadto w murowanej partii poddasza nawy, w ścianach wzdłużnych między wiązarami nr 11 i nr 12 po obu stronach znajduje się szerokie rozkucie, z zachowanymi żelaznymi kotwami pierwotnych narożników ścian (il. 9). Pozostałość ta świadczy, że wcześniej w tym miejscu na całej wysokości wznosiła się poprzeczna ściana.

Na podstawie przeprowadzonej analizy wszystkich wiązarów wyodrębniono dwa zasadnicze układy konstrukcyjne oraz określono ich rozwarstwienie chronologiczne. Do pierwotnych elementów należy większość krokwi, belek wiązarowych oraz częściowo jętek wiązarów nr 2-11. Najlepiej zachowany jest pełny wiązar ze storczykiem nr 11 (il. 10). Zupełnie inny układ konstrukcyjny, chociaż związany również z pierwszym kościołem, tworzą wiązary nr 12-16, w których dodatkowo wykorzystano wtórne elementy (np. budulec na zastrzały w nr. 15$)^{37}$. Układ ten wraz z ramami wzdłużnymi zachowany jest prawie w całości ${ }^{38}$. Na jego pierwotny charakter wskazują ślady w szczycie wschodnim. Brak połączenia wiązarów nr 11 i 13, inna strona odwiązania i odmienny system znaków montażowych świadczą o tym, że konstrukcje te nigdy integralnie nie były ze sobą połączone. Elementami późniejszymi są wiązary nr 11a i 17, a także wszystkie miecze stopowe, przypustnice oraz obecne ramy stolcowe.

Wybrane elementy pierwotnych układów konstrukcyjnych wiązarów nr 2-11 oraz $12-16$ poddano badaniom dendrochronologicznym ${ }^{39}$. Nieste-

brak znaków; nr 15 - znak $V$ sangwiną dla jętki i zastrzałów po stronie północnej; nr 16 i 17 - brak znaków.

36 Obecny wiązar nr 1 jest w całości wtórny, ślad na szczycie jest jednak analogiczny do pełnego wiązara storczykowego, jak nr 11.

37 Na tym etapie badań nie można stwierdzić, czy elementy te pochodzą z konstrukcji nr 1-11.

38 Rama środkowa, choć z wtórnego materiału, tworzy pierwotne usztywnienie wzdłużne. Wtórne są wiązary nr 11a i 17.

39 Próbki pobrano z belek wiązarów nr 2, 3, 13, 15, 16, krokwi północnej wiązara nr 2, storczyka wiązara nr 11. Zob. Ważny, „Badania”, nr 13-18. 
ty, brak słojów podkorowych uniemożliwił datowanie roczne elementów z pierwszej grupy: podobnie jak w przypadku omówionych elementów prezbiterium, ustalono jedynie, że pochodzą one z drzew ściętych po 1577 , po 1607 oraz po 1620 roku. Biorąc pod uwagę najmłodszą datę i informacje historyczne, należy założyć, że konstrukcja ta musiała powstać po roku 1622, lecz wcześniej niż przed 1628 rokiem. Elementy więźby wykonano z sosny i jodły miejscowego pochodzenia. Dodatkowo na dwufazowość zarówno więźby, jak i murów wskazują bruzdy i kotwy po pierwotnej ścianie szczytowej pomiędzy wiązarami nr 11 a 12. Dokładne datowanie roczne uzyskano tylko dla elementów konstrukcji nr 12-16: datą początkową jest rok 1627/1628, natomiast końcową 1628/1629. Z taką chronologią są zgodne dane historyczne oraz data na portalu wejściowym. Należy zatem założyć, że układ wiązarów po stronie wschodniej pochodzi z czasu zakończenia budowy kościoła w obecnej długości, czyli z 1628 roku.

Kolejne zmiany wprowadzono prawdopodobnie w trakcie rozbudowy klasztoru na przełomie lat czterdziestych i pięćdziesiątych XVII wieku ${ }^{40}$. Zdemontowano wiązar nr 17 i założono dwa nowe: nr 11a i $17^{41}$, a odmienny układ pozwolił na wybicie okna i wejścia na poddasze z nowo powstałego przedsionka. Wydaje się, że dopiero później zlikwidowano ramy storczykowe, wprowadzając nowe stolce i częściowo jętki - te przekształcenia należy wiązać już z XIX stuleciem lub nawet początkiem XX wieku ${ }^{42}$. Niestety, nie wiadomo dokładnie, kiedy dodano przypustnice.

Rozwarstwienie chronologiczne umożliwiło wykonanie rekonstrukcji układu wiązarów nr 1-11 oraz 12-17. W momencie zakończenia budowy kościoła w 1628 roku więźba składała się z dwóch niezależnych systemów. Wiązary nr 1-11 były konstrukcją storczykową, zredukowaną poprzecznie i podłużnie w co drugim wiązarze. Wiązar pełny (oznaczony na il. 6 literą D) znajdował się pierwotnie na osi wiązarów nr 3, 5, 7, 9, 11 i miał układ czterojętkowy. Storczyk przechodził przez wszystkie jętki, dochodząc do kalenicy, a zawieszony był na dwóch parach zastrzałów, krzyżujących się z dwiema kolejnych parami. Dodatkowo miecze łączyły belki i krokwie. Nieco powyżej mieczów stopowych wychodził podłużny zastrzał sięgający do drugiej jętki.

40 Czas budowy wieży i przedsionka określono na podstawie badań dendrochronologicznych konstrukcji wieży. Zob. Ważny, „Badania”, nr 1-5.

${ }_{41}$ Mają one taki sam układ konstrukcyjny, odbiegający od układu innych wiązarów.

42 Badania dendrochronologiczne podwaliny i miecza z tej fazy budowlanej nie przyniosły żadnego wyniku. Zob. Ważny, „Badania”, nr 11, 12. 
W krokwi nie ma natomiast śladu osadzenia dolnej jętki - dochodzić musiała ona zapewne do tego właśnie zastrzału. Poniżej trzech dolnych jętek ze storczyka wychodziły rygle tworzące wraz z podwaliną ramę wzdłużną usztywniającą. Dwa ślady po zastrzałach w storczyku (gniazda nieco poniżej grzędy i trzeciej jętki zastrzałów idących w górę) sugerują formę usztywnienia wzdłużnego. Dodatkowo po bokach były umieszczone ramy stolcowe. Wiązary zredukowane (na il. 6 oznaczone jako F) znajdowały się w osi wiązarów nr 2 i 6 . Brak w nich storczyków oraz trzeciej jętki, a pierwsza od dołu (w przeciwieństwie do wiązarów pełnych) połączona była z krokwiami. Występowały w nich stolce dwóch ram bocznych, które były usztywnione od góry za pomocą zastrzałów, przechodzących przez jętkę do krokwi. Być może drugi miecz usztywniał słup z jętką, dowodów na to jednak brak ${ }^{43}$. Od dołu stolce na płatwi połączone były z belką wiązarową dwoma krótkimi mieczami poprzecznymi. Dodatkowo krokwie z belką wiązarową usztywniono długimi mieczami. Wiązary zredukowane bez storczyka i stolców (na il. 6 oznaczone jako E) znajdowały się w osi wiązarów nr 4, 8, 10.

Nieco inną konstrukcję miały wiązary nr $12-17$. Wiązar pełny (na il. 5 oznaczony jako A) mieścił się w osi nr 13, 15, 17. Był to układ dwujętkowy ze storczykiem i ramą stolcową. Storczyki dochodziły jedynie do rygla pod grzędą i zawieszone były od góry na dwóch krzyżujących się parach zastrzałów. Stolce z belkami wiązarowymi usztywnione były za pomocą pary mieczy stopowych. Krokiew z belką oraz krokiew z przypustnicą dodatkowo łączyły się również krótkimi mieczami. Wiązary zredukowane (na il. 5 oznaczone jako B) były położone na osi wiązarów $\mathrm{nr} 12,14,16$. Nie miały one storczyka ani stolców. Belka wiązarowa łączyła się z krokwiami za pomocą długich mieczy.

Zachowane elementy pozwalają również na rekonstrukcję ram wzdłużnych. Storczyki rozpięte między podwaliną a dwoma ryglami usztywnione były mieczami stopowymi, powyżej zaś dwoma zastrzałami tworzącymi krzyż św. Andrzeja. W ramach bocznych stolce znajdowały się zawsze na osi wiązara, łączyły się podłużnie z mieczami i płatwią.

\section{Wnioski}

Przeprowadzona analiza drewnianych konstrukcji dachowych powiązanych z murami i szczytami kościoła w zespole klasztornym Karczówka pozwala

43 Na il. 6 oznaczono go czerwonym kolorem. 
wysnuć szereg wniosków. W głównej mierze dotyczą one powstania i późniejszych przekształceń kościoła. Rekonstrukcja pierwotnego układu więźby umożliwia także jej charakterystykę na tle innych zespołów konstrukcyjnych $\mathrm{z}$ tego czasu.

Z ustalonego rozwarstwienia i rekonstrukcji drewnianych części obiektu wynika, że pierwotny kościół (lub kaplica) miał długość połowy dzisiejszej nawy i zajmował przestrzeń pierwszego przęsła od zachodu. Z tego okresu zachowała się konstrukcja dachowa (wiązary nr 2-11) i ślad pierwotnej elewacji wschodniej. Odcisk na szczycie zachodnim oraz strona odwiązania wiązarów pozwalają wysnuć hipotezę, iż najpierw odwiązano więźbę nad nawą, potem wymurowano szczyt zachodni, a na końcu zamontowano więźbę prezbiterium ${ }^{44}$.

Należy zatem zgodzić się z poglądem Józefa Zdanowskiego odnośnie do etapowości powstania kościoła. Kwestią nierozwiązaną pozostaje jedynie budowa prezbiterium. Z jednej strony wiadomo, że więźba została odwiązana po wymurowaniu szczytu, który od strony zachodniej był tynkowany. Dodatkowo wymurowano w nim dwa symetryczne otwory, które pierwotnie nie musiały pełnić funkcji komunikacyjnej między poddaszami. Te elementy mogą świadczyć o późniejszym dostawieniu prezbiterium. Taka hipoteza może ponadto skłaniać do ostrożnego wniosku, że kościół mógł być pierwotnie orientowany, a prezbiterium znajdowało się w miejscu dzisiejszego przęsła wschodniego. Z drugiej strony pierwotny układ konstrukcyjny, sposób połączeń oraz system znaków montażowych więźby prezbiterium wykazuje szereg podobieństw do wiązarów nr 2-11 nawy ${ }^{45}$, a to może sugerować budowę nawy i prezbiterium $\mathrm{w}$ jednej tej samej fazie. Na obecnym etapie badań problem ten pozostaje jednak nierozstrzygnięty ${ }^{46}$. Najmłodsza data ścinki drzew (po 1620 r.) oraz informacje historyczne pozwalają na datowanie pierwszego budynku po 1622 (epidemia) a przed 1628 rokiem. Według Zofii Stobieckiej ściany świątyni stać już musiały w 1624 roku. W drugim etapie wydłużono nawę o jedno przęsło, zadaszając ją wiązarami nr 12-17 po stronie wschodniej. Na końcu wymurowano szczyt wschodni. Dwa filary z arkadą pomiędzy przęsłami nawy, które

${ }_{44}$ Wiązar nr 5 nad prezbiterium odwiązany jest od środka, brak również jakichkolwiek śladów na szczycie. Natomiast ślad po pierwotnej więźbie zachował się na wschodnim szczycie nawy.

45 Zdecydowanie większe różnice zauważalne są w wiązarach nr 1-11 oraz 12-17 nawy.

46 Postuluje się ponowne wykonanie badań dendrochronologicznych wszystkich zachowanych oryginalnych elementów. 
zidentyfikowała na archiwalnym rzucie Anna Adamczyk, należy zatem uznać za fragment rozkutej pierwotnej elewacji. Rozbudowany kościół w 1628 roku składał się więc z małego prostokątnego prezbiterium i dwuprzęsłowej nawy. Elewacja frontowa (wschodnia) na osi środkowej miała portal.

W odniesieniu do rekonstruowanych układów więźb należy stwierdzić, że miały one konstrukcję storczykową (prezbiterium) lub mieszaną stolcowo-storczykową z redukcją podłużną i poprzeczną (oba zespoły w nawie). Storczyki zawieszone były na szeregu krzyżujących się zastrzałów. Nie podwieszały ich jętki ani krokwie w kalenicy. Najciekawiej przedstawia się układ konstrukcyjny nawy z wiązarami $\mathrm{nr} 2-11$. Odnaleziono tylko dwa wiązary (nr 2 i 6) ze stolcami ramy wzdłużnej, natomiast storczyk znajdował się w co drugim wiązarze. Nie do końca jest jasne połączenie w nich dolnej jętki z krokwią (w której brak śladów po jętce). Musiała ona dochodzić do skośnego zastrzału łączącego krokiew i drugą jętkę od dołu. Rozwiązanie takie właściwie nie jest spotykane. Znane są natomiast układy, w których element poziomy nie dochodził do krokwi i wtedy pełnił funkcję rozporu pomiędzy leżącymi stolcami. Konstrukcje mieszane ze storczykiem oraz stolcami stojącymi i leżącymi znane są już od XV stulecia, z tym, że znajdowały się one na różnych poziomach wiązara ${ }^{47}$. Ich przykłady z XVII wieku odnaleźć można na Mazow$\mathrm{szu}^{48}$, Pomorzu ${ }^{49}$, także na Śląsku ${ }^{50}$. Układ podobny do analizowanego wiązara ze storczykiem oraz leżącymi stolcami występuje w kościele pw. św. Macieja we Wrocławiu z drugiej połowy XV wieku. Tworzy go więźba ze storczykiem zawieszonym w kalenicy, na jętkach i krzyżujących się zastrzałach; rama o stolcach leżących jest usztywniona przez zastrzały przechodzące od krokwi do środkowej jętki, a dolna jętka sięga bezpośrednio do stolców ${ }^{51}$.

47 Günter Binding, Das Dachwerk auf Kirchen im deutschen Sprachraum vom Mittelalter bis zum 18. Jahrhundert (München: Deutscher Kunstverlag, 1991), 162-164.

48 Maciej Warchoł, Historyczne więźby dachowe kościołów w Warszawie (Warszawa: Miasto Stołeczne Warszawa, 2015), 68-69.

49 W więźbie kościoła pw. św. Józefa w Gdańsku z 1668 r. stolce leżące łączyły się z wieszakiem. Por. Fritz Heyn, Die Danziger Dachkonstruktionen (Ihre konstruktive und historische Entwicklung) (Danzig: 1913), Tafel 9; Marek Gogolin, Więźby dachowe kościołów Pomorza od końca XIII do połowy XIX w. Przekształcenia typów i rozwiązań konstrukcyjnych (Bydgoszcz: Wydawnictwo UKW, 2008), 124-125. Podobne rozwiązania typologiczne przedstawia również Tajchman, „Propozycja”, 27.

50 Ulrich Schaaf, „Barocke Dachwerk in Schlesien. Stand der Forschung - Baubetrieb und Bautechnik am beispiel der Dachkonstruktion der Friedenskirche Schweidnitz/Świdnica“, w Dachkonstruktionen der Barockzeit in Norddeutschland und im benachbarten Ausland, red. Paul Zalewski (Petersberg: Michael Imhof Verlag, 2009), 168.

51 Binding, Das Dachwerk, 168-169. 
Podstawowa różnica układów zastosowanych we wszystkich innych (poza Karczówką) obiektach polega jednak na tym, że nie występują w nich jednocześnie ramy o stolcach leżących i stojących wraz ze storczykiem. Szerokość kościoła w Karczówce jest stosunkowo niewielka (około $10 \mathrm{~m}$ ) i użyta w nim konstrukcja o dużej liczbie krzyżujących się zastrzałów i trzech ramach wzdłużnych wydaje się zdecydowanie przewymiarowana. Na belkach wiązarowych i na krokwiach nie odnaleziono żadnych śladów po ramie o stolcach leżących. W rekonstrukcji założono zatem hipotetycznie połączenie dolnej jętki z podłużnym zastrzałem na nakładkę $e^{52}$.

Omówiona więźba kościoła w Karczówce jest zatem z jednej strony typowym siedemnastowiecznym przykładem mieszanej konstrukcji dachowej z ramą storczykową i stolcową. Z drugiej wszakże strony - zastosowano w niej dość nietypowe rozwiązania, rozmiary układu zaś znacznie przekraczają potrzeby kubatury. W dotychczasowej literaturze konstrukcja ta była zupełnie pomijana, tymczasem w wyniku jej analizy udało się znacznie pogłębić wiedzę na temat dziejów budowy świątyni. Dlatego należy postawić postulat intensyfikacji badań nad drewnianymi konstrukcjami dachowymi zabytków architektury sakralnej na ziemi świętokrzyskiej. Pozwoli to przynajmniej częściowo zweryfikować dotychczasową znajomość ich historii budowlanej. Ponadto po rozpoznaniu większej liczby układów można będzie bliżej scharakteryzować ich rozwiązania konstrukcyjne, a także warsztaty ciesielskie, które je wykonały.

52 Na il.6 oznaczono ją czerwoną kreską. 


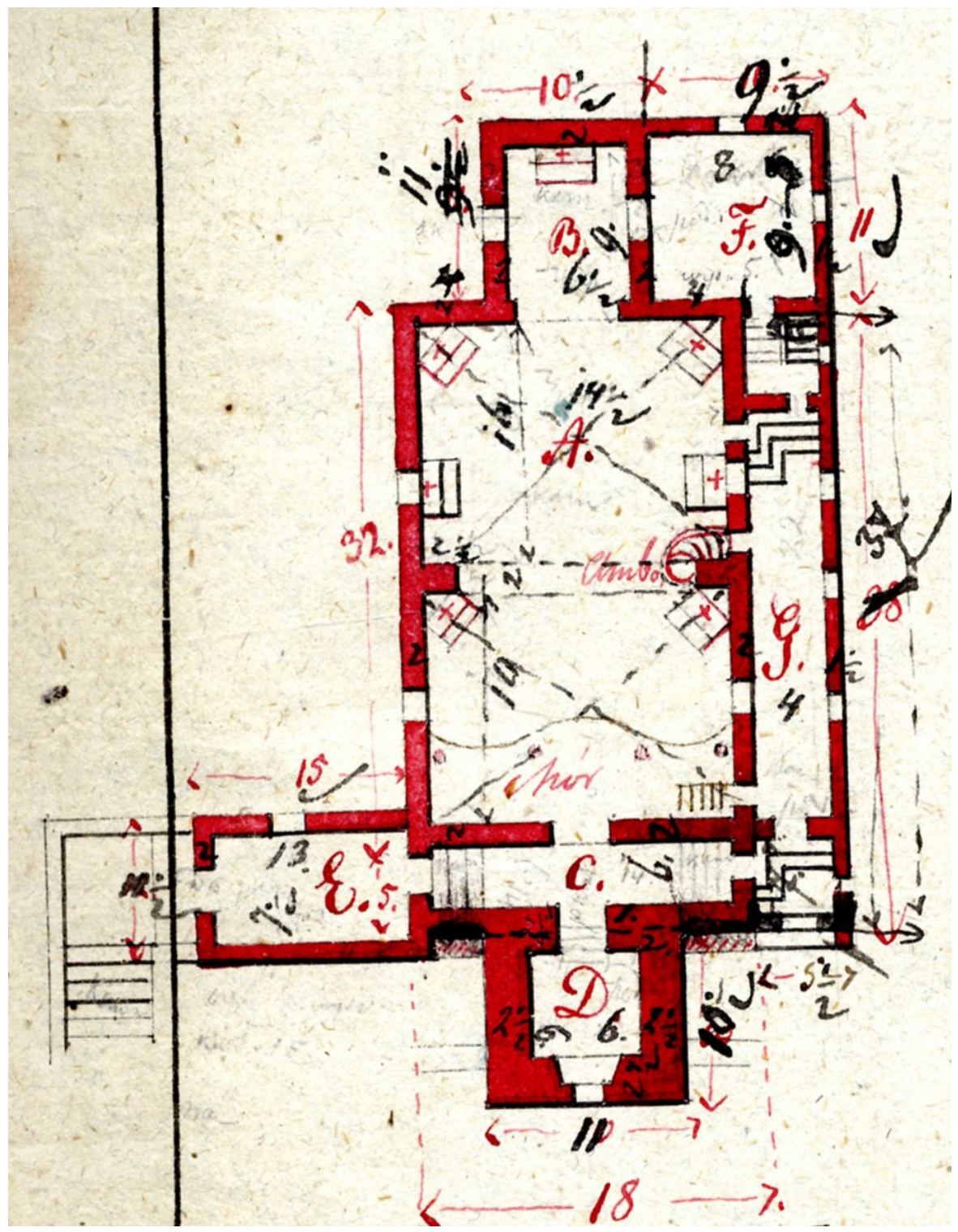

1. Kościół w zespole klasztornym Karczówka (Kielce). Rzut przyziemia z 1845 r. Zbiory Archiwum Państwowego w Kielcach, Dyrekcja Ubezpieczeń, sygn. 57, k. 41 (kopia w zbiorach klasztoru). 


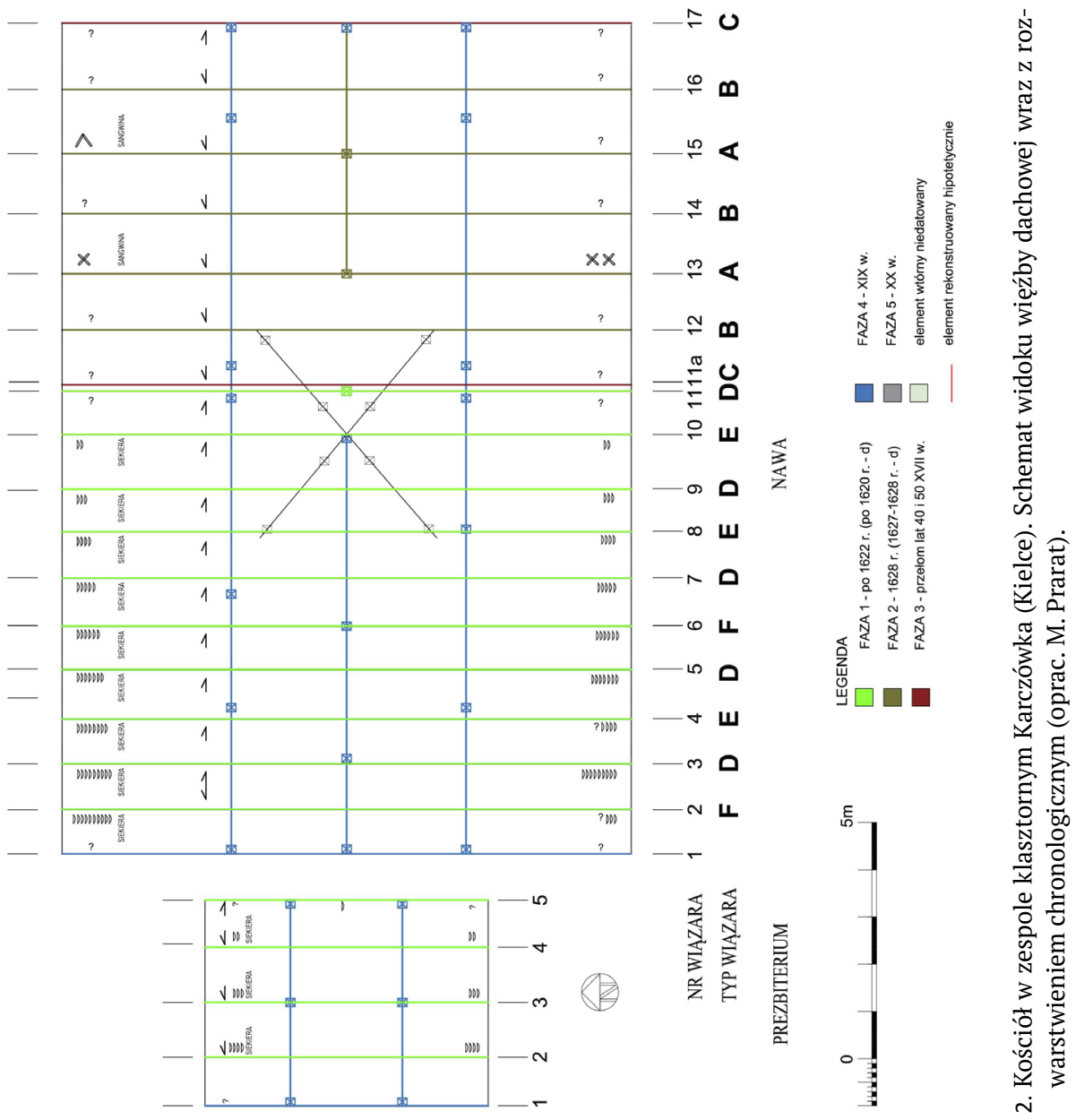



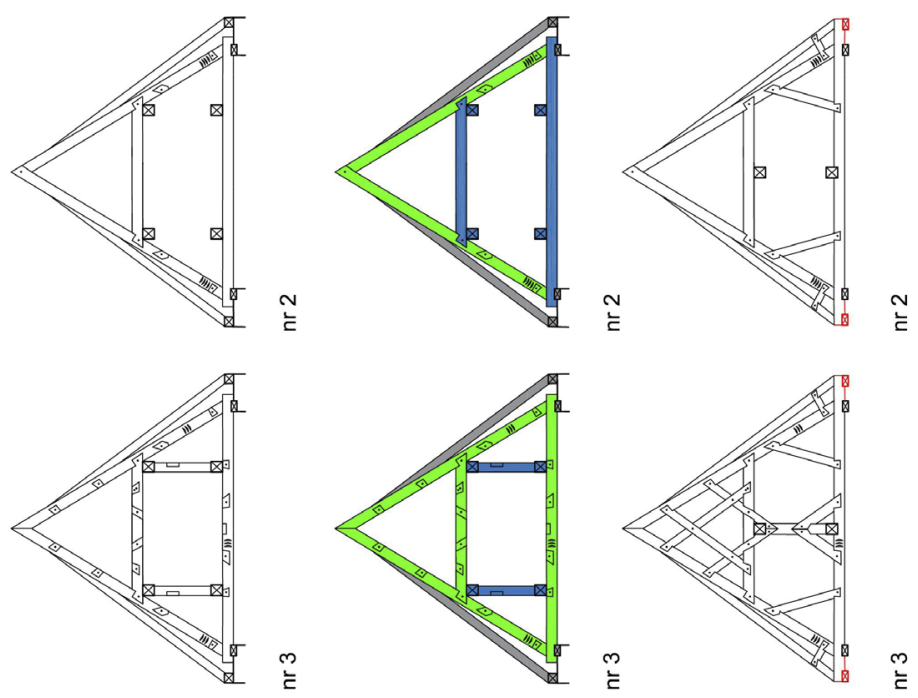

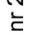
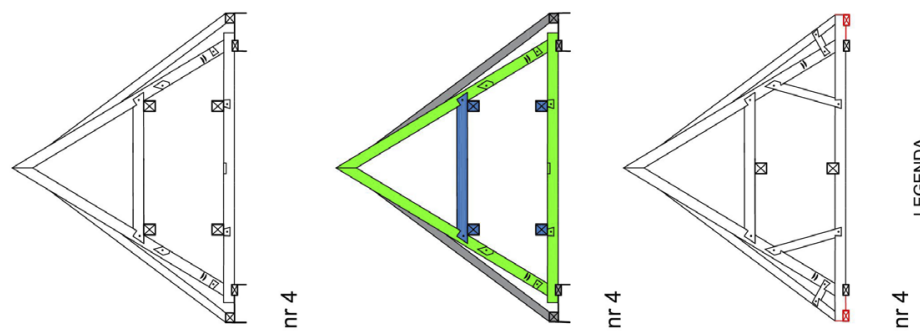

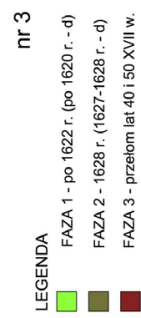

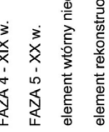

$\square \square \square \mid$
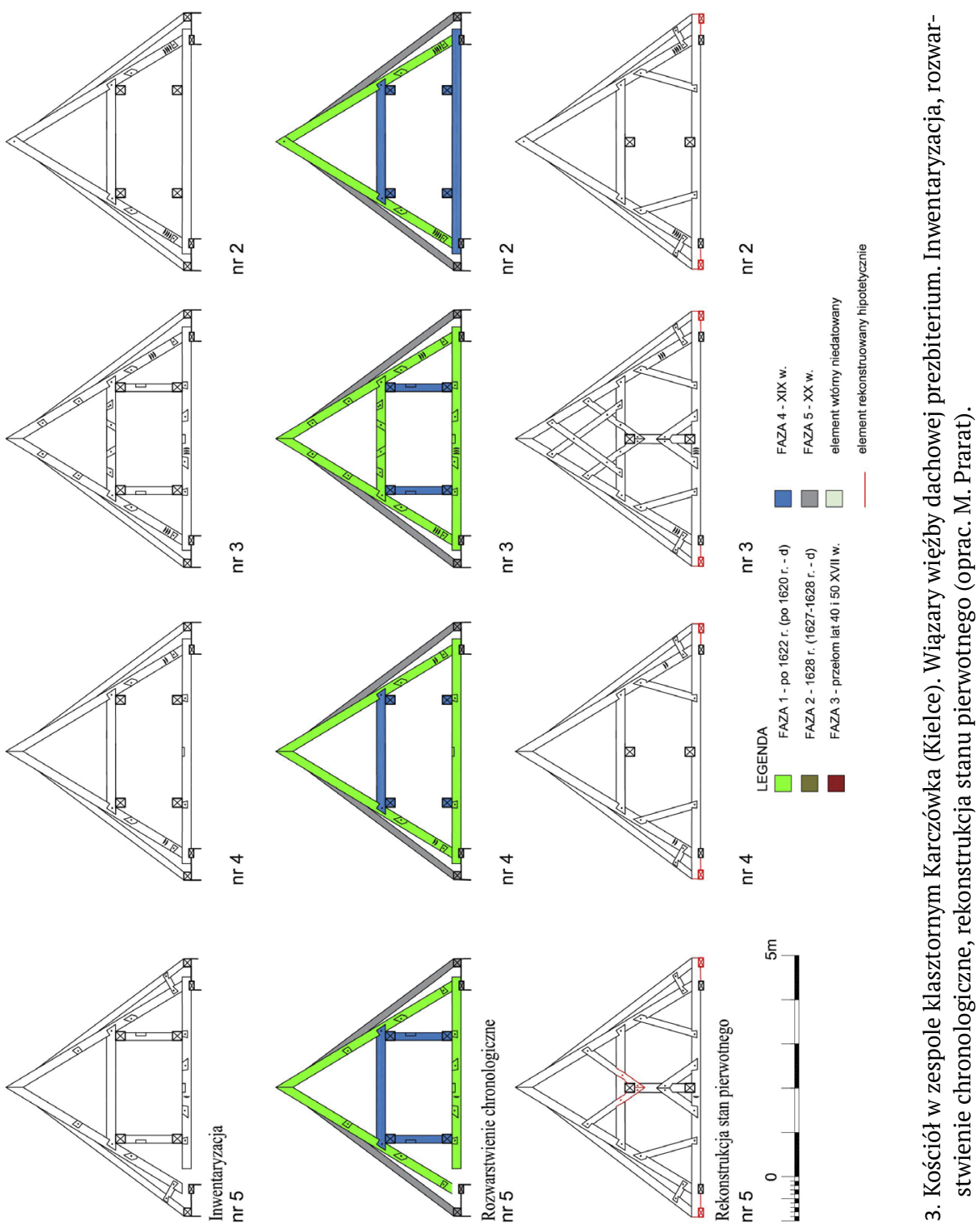

웡 


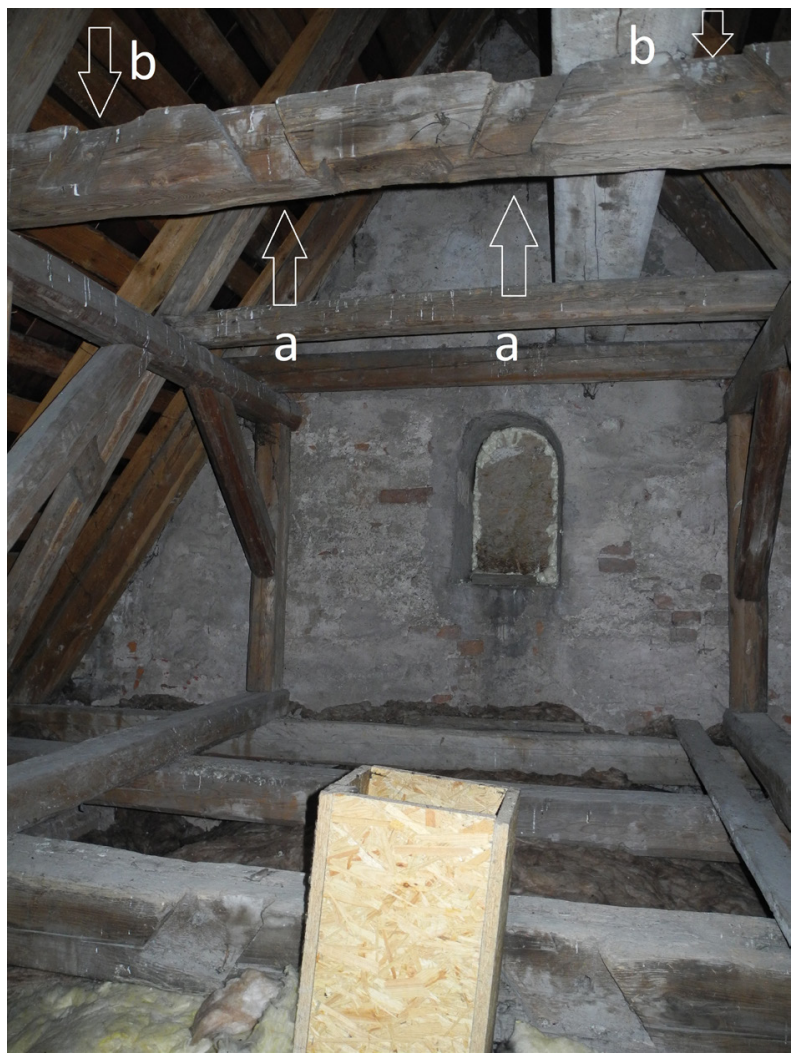

4. Kościół w zespole klasztornym Karczówka (Kielce). Widok na trzeci wiązar prezbiterium od strony odwiązania. Na jętce zachowane gniazda po złączach. Oznaczenia: a - ślad po przekładce zastrzałów podwieszających storczyk; b - ślad po nakładkach zastrzałów krzyżujących się z wyżej wymienionymi (fot. M. Prarat, 2017). 

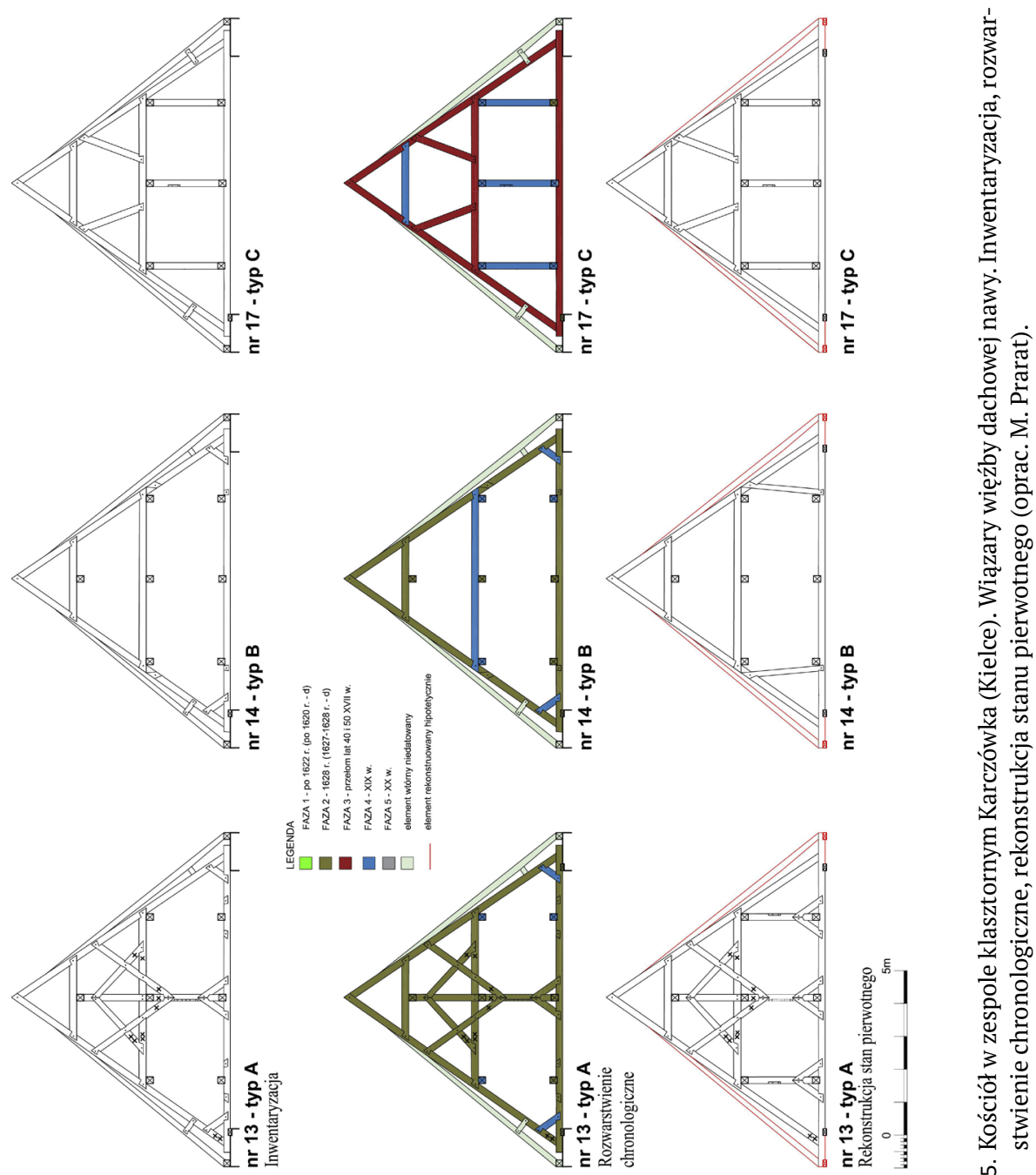

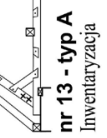
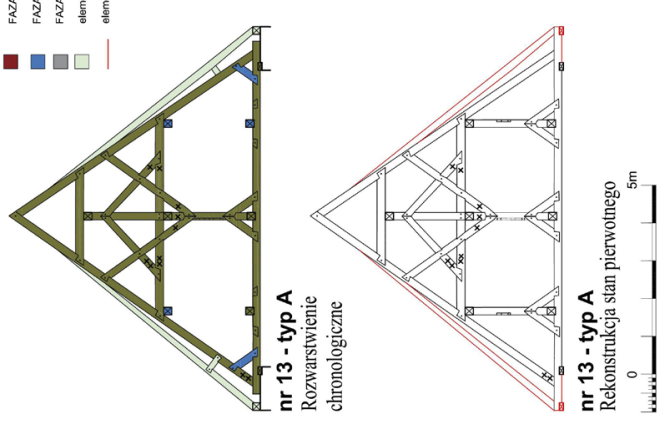

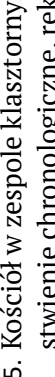


[107]
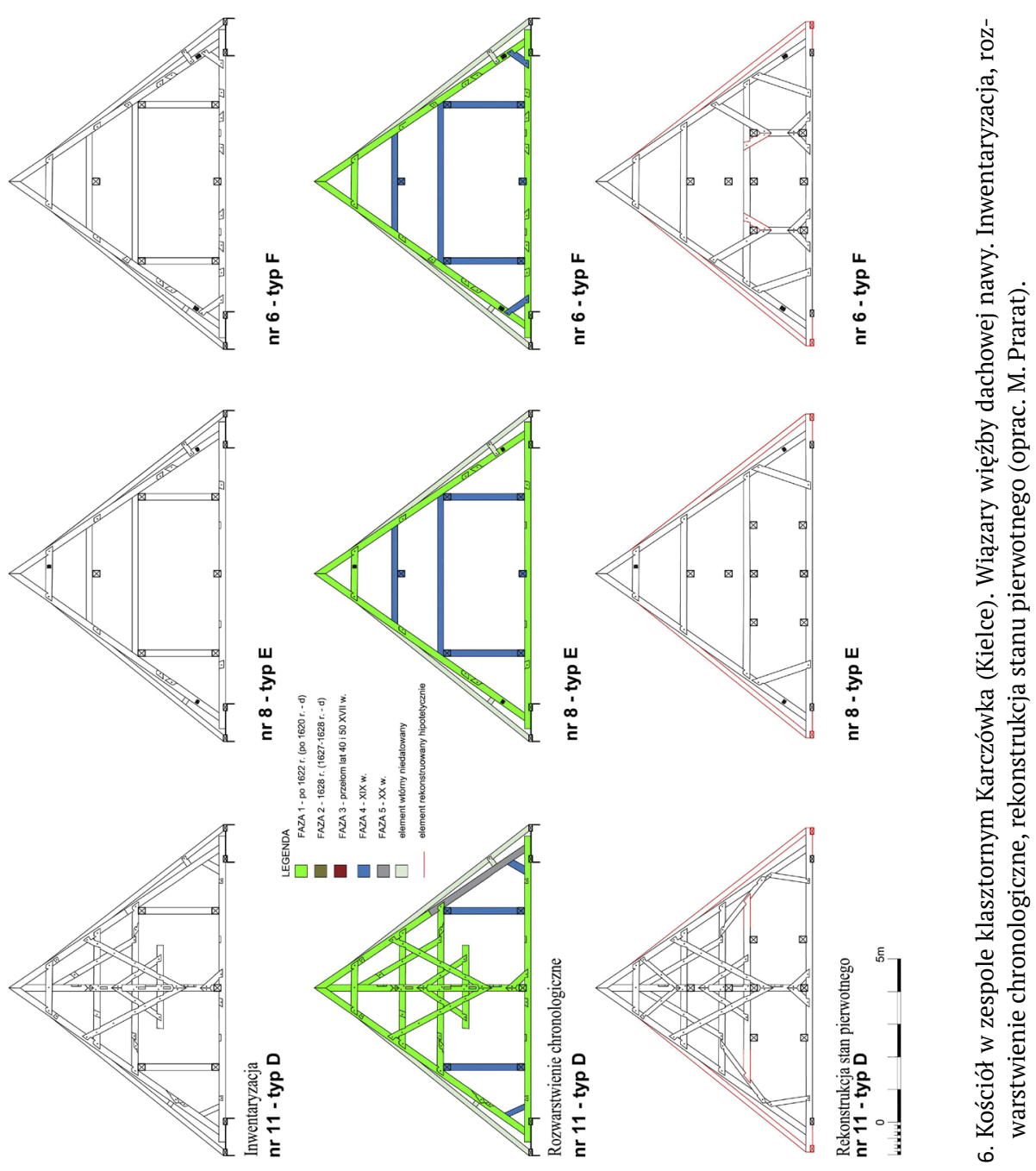


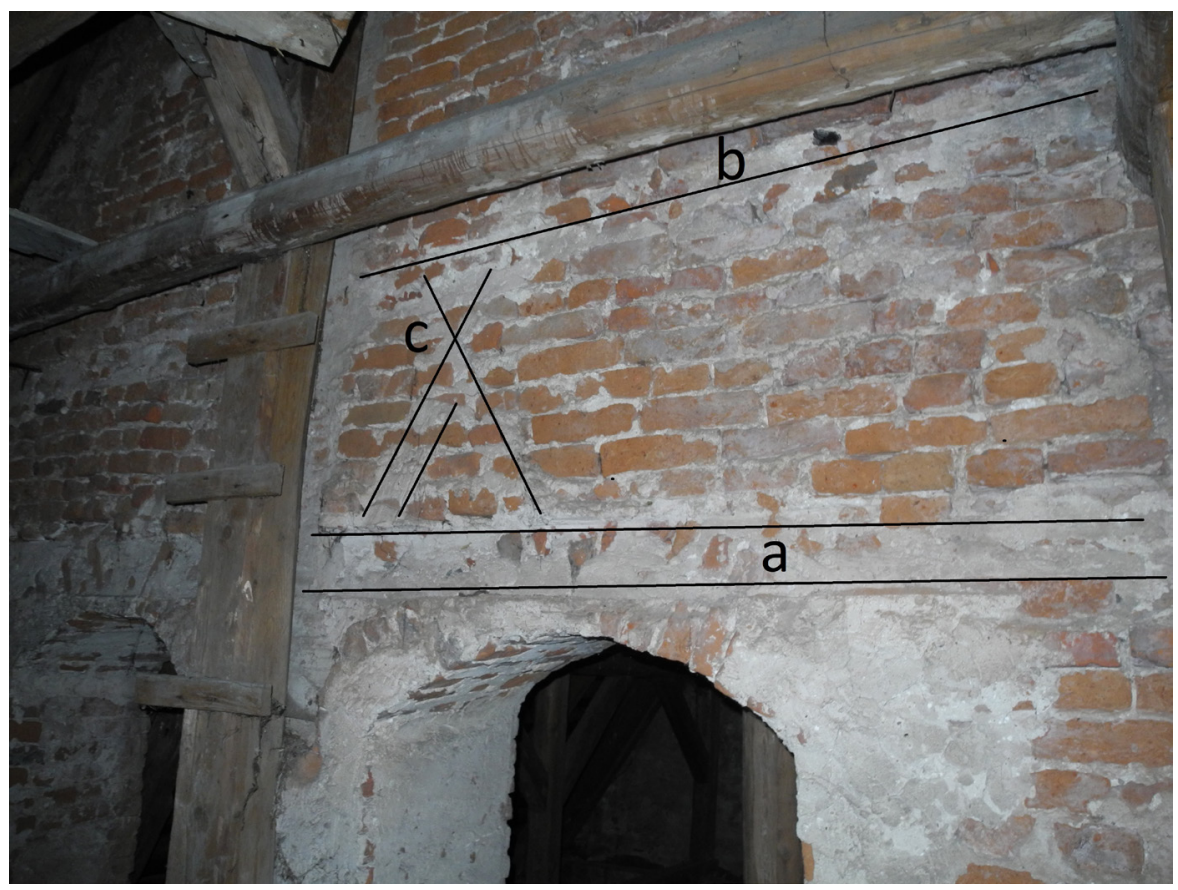

7. Kościół w zespole klasztornym Karczówka (Kielce). Szczyt zachodni od strony zachodniej. Widoczny odcisk pierwotnej konstrukcji. Oznaczenia: a - ślad po dolnej jętce, b - ślad po środkowej jętce, c - ślad po zastrzałach (fot. M. Prarat, 2017). 


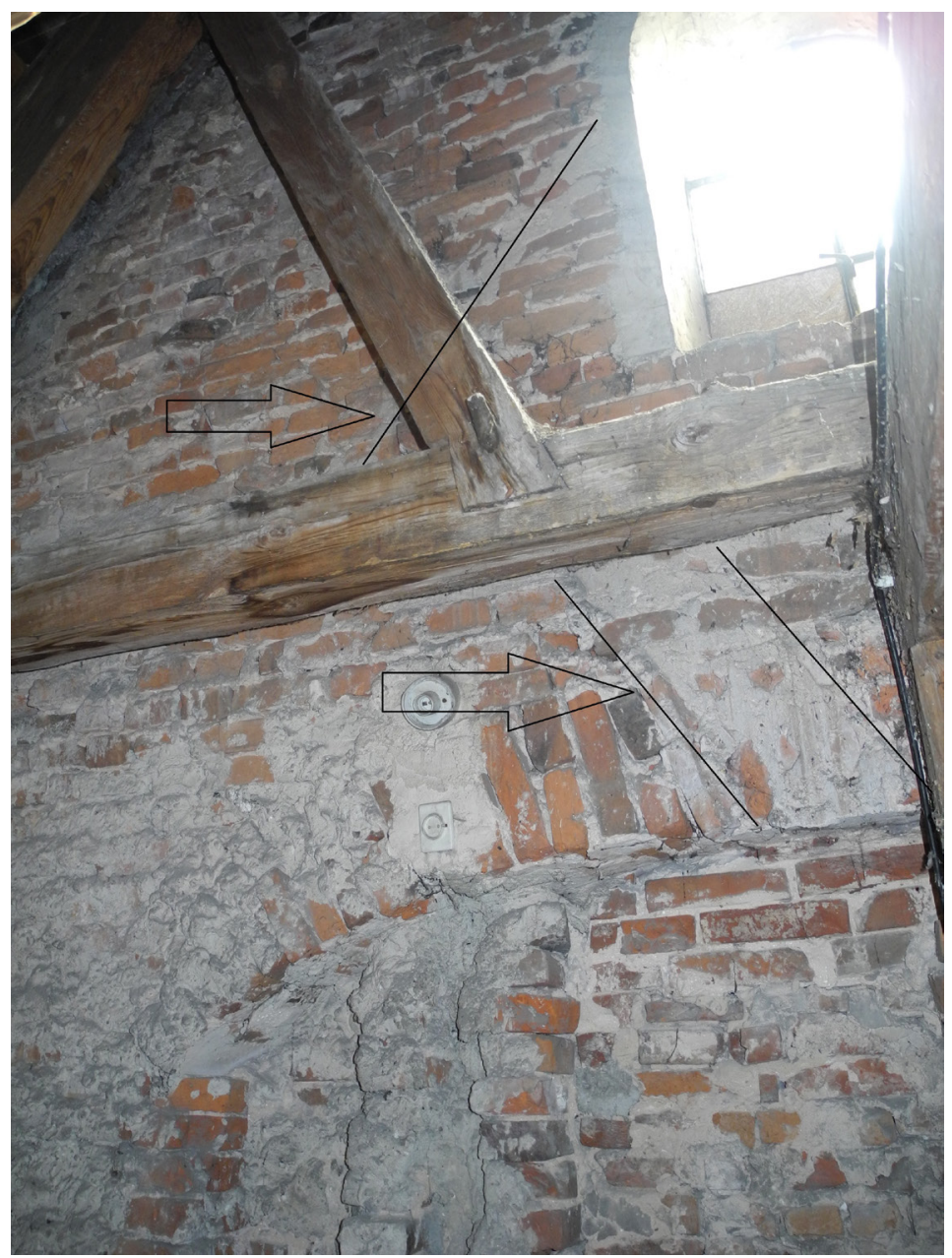

8. Kościół w zespole klasztornym Karczówka (Kielce). Wiązar wschodni od strony wschodniej. Widoczne ślady zastrzałów pierwotnej więźby dachowej (fot. M. Prarat, 2017). 


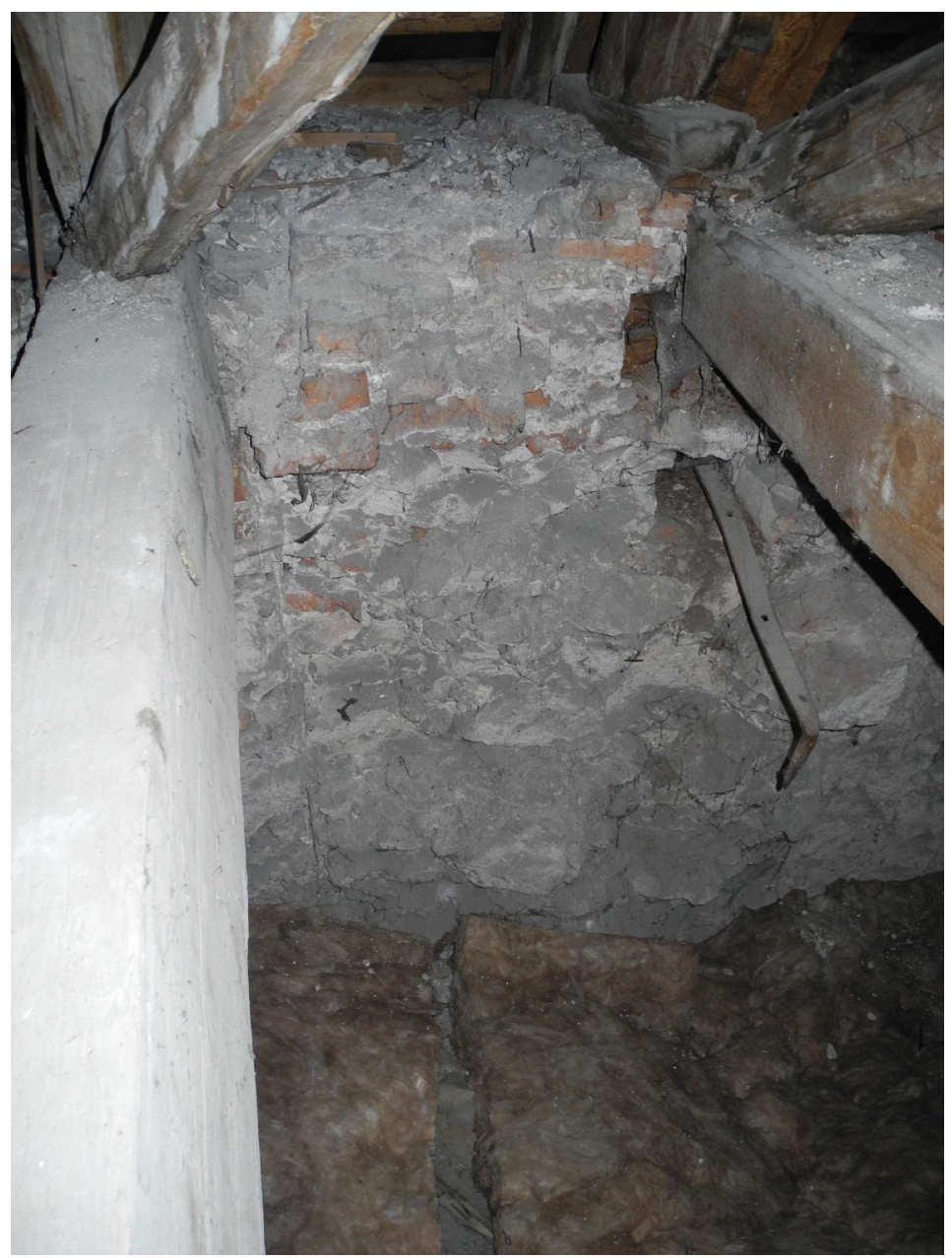

9. Kościół w zespole klasztornym Karczówka (Kielce). Mur ściany północnej nawy. Pomiędzy wiązarami nr 11 i 12 widoczna rozkuta struktura pierwotnej elewacji wschodniej (fot. M. Prarat, 2017). 


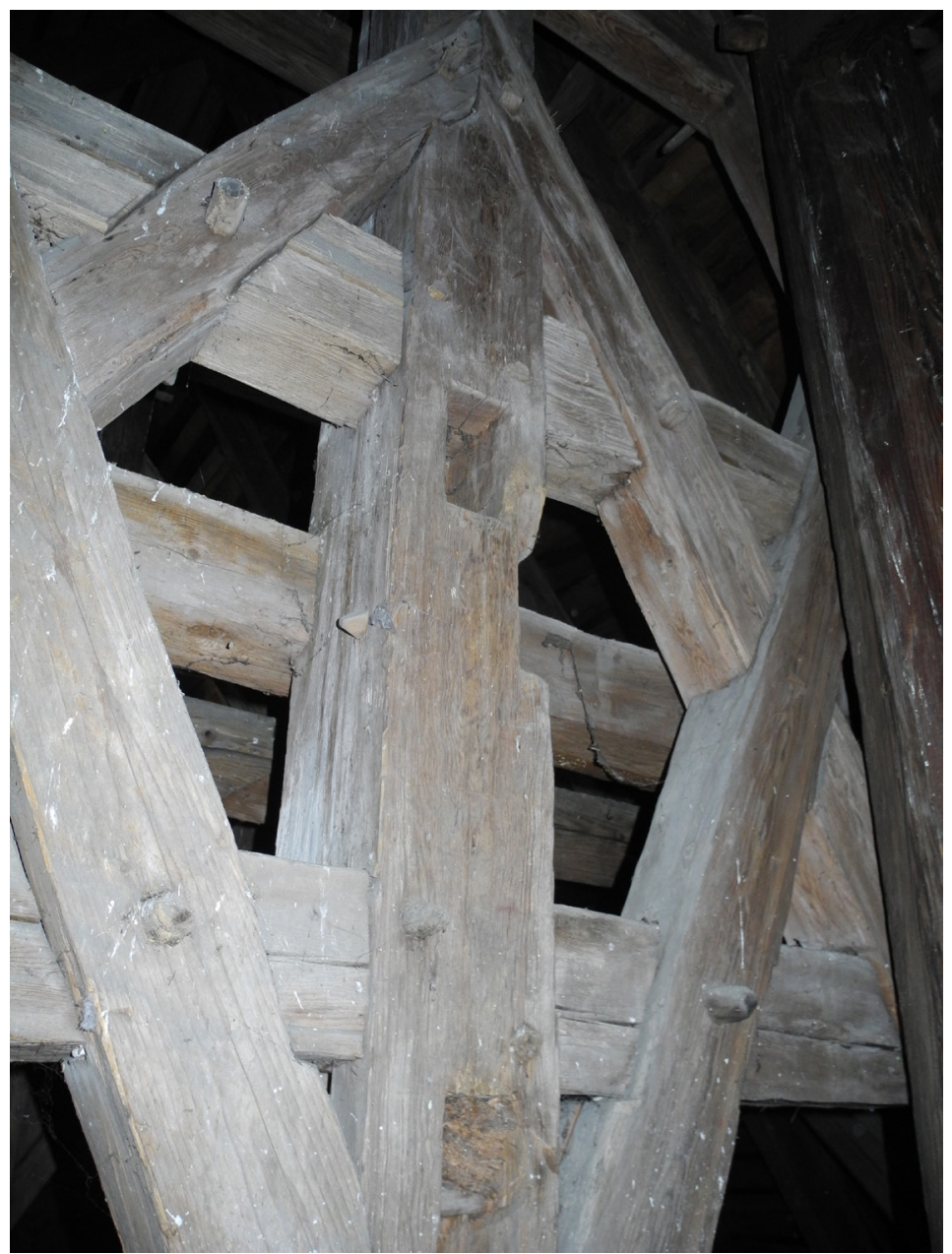

10. Kościół w zespole klasztornym Karczówka (Kielce). Więźba dachowa nawy. Wiązar pełny, storczykowy nr 11 od strony odwiązania (fot. M. Prarat, 2017). 


\section{Bibliografia}

Adamczyk, Anna. „Architektura zespołu klasztornego na Karczówce”. W Karczówka. Historia, literatura, architektura, przyroda, red. J. Olszewski, 51-72. Kielce: Kieleckie Towarzystwo Naukowe, 1995.

Binding, Günter. Das Dachwerk auf Kirchen im deutschen Sprachraum vom Mittelalter bis zum 18. Jahrhundert. München: Deutscher Kunstverlag, 1991.

Blaschke, Kinga. „Kościół na Karczówce. Zapomniane sanktuarium św. Karola Boromeusza”. W Święty Karol Boromeusz a sztuka w Kościele powszechnym, w Polsce, w Niepołomicach, red. Piotr Krasny, Michał Kurzeja, 77-99. Kraków: DodoEditor; Niepołomice: Muzeum Niepołomickie w Zamku Królewskim, 2013.

Dzieje Karczówki w Kielcach w latach 1624-2024. T. 1 Początki fundacji, insygnia, fundator, red. Jerzy Michta. Kielce: Muzeum Historii Kielc, 2016.

Gogolin, Marek. Więźby dachowe kościołów Pomorza od końca XIII do połowy XIX w. Przekształcenia typów i rozwiązań konstrukcyjnych. Bydgoszcz: Wydawnictwo UKW, 2008.

Guttmejer, Karol. Guido Antonio Longhi. Działalność architektoniczna w Polsce. Warszawa: Wydawnictwo Neriton, 2006.

Heyn, Fritz. Die Danziger Dachkonstruktionen (Ihre konstruktive und historische Entwicklung). Danzig: 1913.

Kukła, Dawid, i Pawlicki Michał. Karczówka. Bibliografia w wyborze. Kielce: Wojewódzka Biblioteka Publiczna w Kielcach, 2012. Dostęp 20.06.2017. http://sbc.wbp.kielce.pl/ Content/16075/KARCZ\%C3\%93WKA bibliografia\%20w\%20wyborze.pdf.

Katalog zabytków sztuki w Polsce. T. 3 Województwo kieleckie, red. Jerzy Łoziński, Barbara Wolff. Z. 4 Powiat kielecki. Oprac. Tadeusz Przypkowski. Warszawa: Państwowy Instytut Sztuki, 1957.

Lewicki, Jakub. „Kilka uwag na marginesie monografii bernardyńskiego zespołu klasztornego na Karczówce pod Kielcami”. Kwartalnik Architektury i Urbanistyki. T 43, z. 3 (1998): 273-280.

Lewicki, Jakub. Recenzja z Karczówka. Historia, literatura, architektura, przyroda, red. Jerzy Leszek Olszewski. Ochrona Zabytków. T 51, nr 2 (1998): 181-187.

Łoziński, Jerzy i Adam Miłobędzki. Atlas zabytków architektury w Polsce. Warszawa: Wydawnictwo „Polonia”, 1967.

Mączyński, Dominik, Jan Tajchman i Maciej Warchoł. „Materiały do terminologii więźb dachowych - podstawowe pojęcia”. Monument. Studia i Materiały Krajowego Ośrodka Badań i Dokumentacji Zabytków 2 (2005): 37-43.

Michałowska, Marta. Zabytkowe tekstylia kieleckie. Warszawa: Ośrodek Dokumentacji Zabytków, 1989.

Morka, Mieczysław. „Figura św. Barbary w klasztorze na Karczówce w Kielcach”. Biuletyn Historii Sztuki. T 40, nr 4 (1978): 377-399.

Moryc, Cyprian. „Galeria portretowa wybitnych bernardynów jako wyraz plastyczny ideału doskonałości zakonnej promowanego w środowisku bernardyńskim w XVII 
i XVIII w.” W Studia nad sztuka renesansu i baroku. T. 10 Programy ideowe $w$ przedsięwzięciach artystycznych w XVI-XVIII wieku, red. Irena Rolska-Boruch, 265-293. Lublin: Towarzystwo Naukowe KUL, 2010.

Piasecka, Anna. „Kronika prac remontowo-konserwatorskich zrealizowanych w zespole kościoła i klasztoru bernardynów na Karczówce w latach 1945-1993”. W Karczówka. Historia, literatura, architektura, przyroda, red. Jerzy Leszek Olszewski, 73-77. Kielce: Kieleckie Towarzystwo Naukowe 1995.

Piaskowska, Beata. „Inwentaryzacja pomiarowo-rysunkowa części wschodniej kościoła pw. św. Karola Boromeusza w zespole klasztornym Karczówka”. Toruń-Karczówka: 2017, Wojewódzki Urząd Ochrony Zabytków w Kielcach.

Pieniążek-Samek, Marta. Tributum Gratitudinis Reddo. Fundacje artystyczne na terenie Kielc w XVII i XVIII wieku. Studium z historii kultury. Kielce: Kieleckie Towarzystwo Naukowe, Wydawnictwo Jedność, 2005.

Prarat, Maciej. „Badania architektoniczne części wschodniej kościoła pw. św. Karola Boromeusza w zespole klasztornym Karczówka”. Toruń-Karczówka: 2017, Wojewódzki Urząd Ochrony Zabytków w Kielcach.

Rosiński, Piotr. Zabytkowe organy w województwie kieleckim. Warszawa: Wydawnictwo Naukowe PWN, 1992.

Schaaf, Ulrich. „Barocke Dachwerk in Schlesien. Stand der Forschung - Baubetrieb und Bautechnik am beispiel der Dachkonstruktion der Friedenskirche Schweidnitz/Świdnica“. W Dachkonstruktionen der Barockzeit in Norddeutschland und im benachbarten Ausland, red. Paul Zalewski, 165-179. Petersberg: Michael Imhof Verlag, 2009.

Schaaf, Ulrich. „Metody i formy dokumentacji badań architektonicznych konstrukcji szkieletowych na wybranych przykładach śląskich Kościołów Pokoju”. W Badania architektoniczne. Historia i perspektywy rozwoju, red. Marian Arszyński, Maciej Prarat, Bożena Zimnowoda-Krajewska, Ulrich Schaaf, 155-183. Toruń: Wydawnictwo Bernardinum, 2015.

Stobiecka, Zofia. „Pobernardyński zespół kościelno-klasztorny na Karczówce”. Rocznik Muzeum Świętokrzyskiego 8 (1973): 275-304.

Tajchman, Jan. „Propozycja systematyki i uporządkowania terminologii ciesielskich konstrukcji dachowych występujących na terenie Polski od XIV do XX w.” Monument. Studia i Materiały Krajowego Ośrodka Badań i Dokumentacji Zabytków 2 (2005): 7-35.

Warchoł, Maciej. Historyczne więźby dachowe kościołów w Warszawie. Warszawa: Miasto Stołeczne Warszawa 2015.

Ważny, Tomasz. „Badania dendrochronologiczne wieży, nawy i prezbiterium kościoła pw. św. Karola Boromeusza w zespole klasztornym Karczówka”. Toruń-Karczówka: 2017, Wojewódzki Urząd Ochrony Zabytków w Kielcach. 
Wic, Janusz. „Klasztor bernardynów, Kielce-Karczówka. Karta Ewidencji Zabytków Architektury i Budownictwa”. Kielce: 1996, Wojewódzki Urząd Ochrony Zabytków w Kielcach.

Wic, Janusz. „Kościół parafialny pw. św. Karola Boromeusza w zespole klasztornym Kielce-Karczówka. Karta Ewidencji Zabytków Architektury i Budownictwa”. Kielce: 1996, Wojewódzki Urząd Ochrony Zabytków w Kielcach.

Wic, Janusz. „Zabudowania gospodarcze w zespole klasztornym Kielce-Karczówka. Karta Ewidencji Zabytków Architektury i Budownictwa”. Kielce: 1996, Wojewódzki Urząd Ochrony Zabytków w Kielcach.

Wic, Janusz. „Zespół klasztorny bernardynów Kielce-Karczówka. Karta Ewidencji Zabytków Architektury i Budownictwa”. Kielce: 1996, Wojewódzki Urząd Ochrony Zabytków w Kielcach.

Zdanowski, Józef. Karczówka pod Kielcami. Kielce: 1928. 